\title{
PEMANFAATAN UBI JALAR, SUSU, DAN BANDREK DALAM PENGEMBANGAN PRODUK MAKANAN
}

\author{
Selvi Novianti \\ Sekolah Tinggi Pariwisata Bandung \\ Email: novianti.selvi@gmail.com
}

How to cite (in APA Style): Novianti, S. (2018). Pemanfaatan ubi jalar, susu, serta bandrek dalam pengembangan produk makanan di desa Alam Endah, kecamatan Rancabali, Kabupaten Bandung (pie susu bandrek). Barista: Jurnal Kajian Bahasa dan Pariwisata, 5(2), Desember 2018, 235-246.

\begin{abstract}
Abstrak: Penelitian ini bertujuan untuk mengembangkan produk makanan di desa Alamendah, Ciwidey, Kab. Bandung sebagai varian oleh-oleh makanan dari daerah tersebut. Metode penelitan yang digunakan adalah metode eksperimen dengan pendekatan kuantitatif. Data diukur melalui uji sensori untuk menentukan profil produk serta uji hedonik untuk mengetahui daya terima masyarakat terhadap produk penelitian. Panelis terdiri dari panelis terlatih dan panelis tidak terlatih. Kemudian data dianalisa dengan menggunakan deskriptif kualitatif dan Uji Friedman. Hasil peneltian menunjukan bahwa pie susu bandrek yang terbuat dari tepung ubi putih dengan proporsi $60 \%$ tepung ubi jalar putih dan $40 \%$ tepung terigu memiliki profil sensori terbaik dengan tingkat penerimaan yang disukai oleh masyarakat. Disarankan untuk melakukan penelitian lanjutan mengenai daya tahan produk terpilih apabila akan dijadikan sebagai produk komersil.
\end{abstract}

Keywords: pie susu, bandrek, ubi jalar, produk makanan

\section{UTILIZATION OF SWEET POTATO, MILK, AND BANDREK IN THE DEVELOPMENT OF FOOD PRODUCTS}

\begin{abstract}
The aim of this research was to develop food product in Alamendah Village as variant of souvenir from related area. The research used experimental method with quantitative approach. Data was measured through sensory test to determine research product profiles and hedonic test to determine community acceptance. Panelist consisted of trained panelists and untrained panelists. Furthermore, data was analyzed with descriptive qualitative method and Friedman test. Results shown that bandrek egg tart which was made from $60 \%$ white sweet potato flour and $40 \%$ wheat flour obtained the best sensory profile while the level of acceptance was favored by community. It is recommended to conduct further research on product shelve live if it will be used as a commercial product.
\end{abstract}

Keywords: egg tart, bandrek, sweet potato, food products 


\section{PENDAHULUAN}

Salah satu daerah yang berkontribusi besar terhadap hasil pertanian di Jawa Barat adalah Kabupaten Bandung (Puspitasari, 2011). Dimana kondisi geografisnya mendukung dengan tananaman pertanian. Desa Alam Endah adalah salah satu desa yang ditetapkan sebagai desa wisata agro berdasarkan ketetapan Dispopar (Dinas Pemuda, Olahraga, dan Pwariwisata) Kabupaten Bandung pada tahun 2010 (Elgad dkk., 2017). Tujuan dari dicetuskannya konsep wisata agro adalah untuk memberikan benefit tidak hanya bagi wisatawan namun juga bagi komunitas local dalam hal ini adalah petani. Dengan adanya agrowisata diharapkan dapat memberikan peluang bagi petani local untuk dapat meningkatkan taraf hidupnya diantaranya adalah dengan menjual hasil tani merka serta produk olahannya. Sehingga didapat kehidupan perekonomian masyarakat local yang berkelanjutan (Puspitasari, 2011). Pada saat ini hasil pertanian seperti strawberry, teh, jahe dan bawang daun memiliki ketersediaan yang yang cukup melimpah, terutama strawberry, dimana varian oleh-oleh berupa produk makanan yang ditemui didominasi dengan produk makanan olahan strawberry (tanpa nama, 2017). Oleh karena itu diperlukan pengembangan produk makanan untuk menambah variasi oleh-oleh yang tersedia di desa Alamendah. Pengembangan produk pangan diperlukan untuk dapat memanfaatkan ketersediaan bahan baku dengan tujuan meningkatkan daya guna sehingga dapat menambah nilai ekonomis serta daya pemuas bagi konsumen (Rosyad, 2016).

Namun, dalam melakukan pengembangan produk pangan selain diperlukan ketersediaan bahan baku juga harus diperhatikan mengenai kesesuaian produk yang dihasilkan dengan keinginan konsumen. Fenomena kue kekinian yang sedang terjadi saat ini dapat dianggap sebagai tantangan bagi pangan tradisional untuk ikut berpartisipasi sehingga eksistensinya dapat dipertahankan. Oleh karena itu diperlukan inovasi, salah satunya adalah dengan menggabungkan produk modern dengan bahan pangan local namun tetap mempertahankan ciri khas kedaerahannya. Karena, produk-produk kue kekinian tersebut dianggap memiliki cita rasa yang sama dimana tidak terdapat nilai autentitasnya sehingga diprediksi tidak akan bertahan lama. Dengan demikian pada akhirnya masyarakat akan tetap kembali kepada produk pangan tradisional (Nurjani, 2018).

Salah satu produk modern yang dikenal oleh masyarakat adalah pie susu. Pie susu adalah produk makanan yang memiliki tekstur kulit yang renyah dan gurih dengan isian campuran susu dan telur (custard) bericita rasa manis dan legit. Pie susu tidak hanya ditemukan di kota Bali, namun juga terdapat di beberapa kota besar di Indonesia. Kulit yang renyah didapat dari penggunaan tepung terigu yang protein rendah dengan campuran mentega, sementara isiannya sering dimodifikasi dengan aneka cita rasa seperti coklat, keju, green tea, strawberry dan lainnya (Pertiwi F., 2014). Produk makanan ini dapat dijadikan sebagai ide dalam pengembangan produk makanan di desa Alamendah dikarenakan popularitas serta sifat modern yang dimiliki. Namun, bahan baku yang digunakan dapat menggunakan bahan pangan local yaitu dengan mengganti sebagian tepung terigu yang digunakan dengan menggunakan tepung ubi jalar, kemudian menggunakan susu sebagai isian yang berasal dari peternakan local serta menambahkan karakter kedaerahan dengan memberikan kombinasi isian dengan tambahan custard bandrek. Bandrek merupakan bentuk dari pemanfaatan jahe yang tersedia di desa Alam Endah. Rempah-rempah yang digunakan sejenis dengan rempah-rempah yang digunakan pada pembuatan kue rempah atau minuman rempah yang disediakan di Negara lain. Oleh karena itu bandrek yang sudah dikenal luas, dengan rasa yang khas serta popular, dimana saat ini bandrek mudah untuk didapat dimanapun terutama setelah adanya situs belanja online, diharapkan dapat diterima oleh masyarakat sebagai produk baru yang memiliki keunikan tersendiri.

Tepung ubi jalar yang digunakan merupakan perwujudan dari misi ketahanan pangan nasional dengan cara mengurangi penggunaan tepung terigu. Dengan kandungan protein yang rendah, tepung ubi jalar dapat dijadikan sebagai pengganti tepung terigu sebanyak $50-100 \%$ dalam pembuatan kue (Koswara, 2013). Selain itu, tepung ubi jalar juga memiliki kandungan 
serat yang berperan baik bagi pencernaan, serta dengan menggunakan tepung ubi jalar dalam pembuatan kue dapat mengurangi penggunaan gula sebesar $20 \%$ bila dibandingkan dengan produk makanan yang menggunakan tepung terigu. Walapupun tepung ini tidak diproduksi di desa Alamendah, namun dengan penggunaanya dapat berperan serta dalam membangun dan mengembangkan industri pembuatan tepung ubi jalar yang sedang berkembang saat ini. Tepung ubi jalar dipilih karena banyak produk makanan yang sudah banyak produk makanan yang dibuat dengan menggunakan tepung tersebut (Bogasari baking school dalam Koswara, 2013).

Tepung ubi jalar memiliki jumlah serat yag lebih banyak dengan jumlah kalori hampir menyamai tepung terigu. Namun, protein yang dihasilkan tidak memadai bagi anak-anak yang sedang mengalami masa tumbuh kembang (Santosa dkk., 2016). Akan teatapi, masih banyak kandungan pada ubi jalar lainnya yang sangat bermanfaat bagi tubuh bila dibandingkan dengan terigu, seperti vitamin C, vitamin B6 kemudian fosfor, kalsium, mangan, zat besi, betakrotin yang baik untuk pencernaan serta memiliki indeks glikemik yang rendah. Kemudian, ubi jalar yang memiliki warna memiliki kandungan antioksidan yang berfunsgi untuk membersihkan radikal bebas, begitu juga dengan ubi jalar ungu dimana perbedaannya terletak dari kandungan antosianin yang berfungsi sebagai senyawa antioksidan. Ubi jalar yang ada di Indonesi terdiri dari ubi jalar putih, kuning, merah, oranye dan ubi jalar ungu.

Kemudian, susu yang berasal dari peternakan setempat digunakan untuk menambah jenis olahan susu yang dihasilkan, Dimana bahan baku utama dalam pembuatan isian pie adalah susu. Sementara bandrek, yang berasal dari bahan baku jahe, adalah minuman tradisional yang berasal dari Jawa Barat. Jika di Negara yang memiliki empat musim menggunakan minuman beralkohol untuk menghangatkan tubuh, maka di Jawa Barat, minuman bandrek dikenal dengan fungsinya untuk menghangatkan tubuh, sangat popular di daerah dataran tinggi seperti di kecamatan Ciwidey dan kecamatan Rancabali tempat desa Alamendah berada. Penggunaan bandrek sebagai variasi rasa dalam pie susu belum pernah ditemukan sebelumnya. Bandrek sering dikonsumsi sebagai minuman dan hanya beberapa yang diolah kembali seperti dalam pembuatan pudding serta es krim. Dengan demikian, pengembangan produk makan sebagai oleholeh di desa Alamendah berupa pie susu bandrek diharapkan dapat memenuhi trend oleh-oleh yang sedang berkembang saat ini dengan tetap mempertahankan nilai dan karakteristik local dengan penggunaan susu dan bandrek sebagai identitas dari desa Alamendah.

\section{TINJAUAN PUSTAKA}

\section{Tinjauan Mengenai Desa Alamendah}

Desa Alamendah terletak di kecamatan Rancabali, kabupaten Bandung, provinsi Jawa Barat. Pada bagian utara, desa Alamendah berbatasan dengan desa Panundaan, kecamatan Ciwidey, sementara pada bagian timur dengan desa Sugihmukti, kemudian desa Patengan pada bagian selatan dan desa Lebak Muncang pada bagian barat. Desa dengan luas 505,6 Ha ditetapkan menjadi desa wisata berdasarkan RIPPDA (Rencana Induk Pengembangan Pariwisata Daerah) Kabupaten Bandung no. 6 tahun 2006 bersama dengan enam desa lainnya yang tergabung dalam satu kawasan agropolitan Ciwidey (Puspitasari, 2011).

Alamendah sendiri dalam bahasa Indonesia memiliki makna alam yang indah. Konsep desa wisata yang diusung adalah konsep agrowisata. Yaitu konsep yang bertujuan untuk mengembangkan pariwisata bersamaan dengan pertanian sehingga tercipta kelestarian lingkungan yang diikuti dengan meningkatnya kesejahteraan petani. Dengan curah hujan yang baik, suhu sejuk $\left(19-24^{\circ} \mathrm{C}\right)$ serta kondisi geografis yang didominasi dengan tegalan, perbukitan dan ladang menjadikan desa alamendah memiliki potensi pertanian yang besar sebagai penghasil komoditas pertanian dan tanaman hortikultura (buah-buahan dan sayuran). Saat ini produk wisata yang ditawarkan di desa Alamendah meliputi: kegiatan agrowisata (petik stoberi, wisata bertani, mengelilingi ladang pertanian), curug meong, kesenian tradisional (pencak silat, tari jaipong, reog, dan lainnya), pemandian air panas, punceling pass, kawah putih, ranca upas, pusat rehabilitasi owa, industry rumahan 
pengolahan oleh-oleh, careuh coffee, pemerahan susu sapi, bersepeda santai, dan camping ground (Elgad, dkk., 2017).

Berdasarkan hasil studi, diketahui bahwa desa Alamendah mampu memenuhi 68.75\% dari keseluruhan permintaan wisatawan (Puspitasari, 2011). Merupakan angka yang paling besar bila dibandingkan dengan enam desa lainnya yaitu desa Ciwidey, desa Pasirjambu, desa Panundaan, desa Sukawening, desa Rawabogo dan desa Nengkelan. Dari ketiga aspek yang diteliti yaitu komoditas pertanian, kegiatan pertanian dan sarana, terdapat beberapa permintaan yang tidak terpenuhi pada aspek sarana, dimana berkaitan dengan aksesibilitas yaitu kondisi jalan yang kecil, sulit untuk dilalui bis, serta kondisi jalan yang tidak mulus secara merata.

Sementara itu, komoditas pertanian yang memiliki proporsi paling besar dalam pengembangan kegiatan agrowisata adalah buah strawberry. Sedangkan, masih ada komoditas-komoditas pertanian lainnya yang juga memiliki potensi seperti permintaan wisatawan untuk lebih mendalami mengenai pengolahan kopi, kemudian komoditas pertanian berupa sayuran (sawi, seledri, daun bawang), jahe, dan teh. Produk pangan dan oleh-oleh juga lebih banyak menggunakan bahan pangan strawberry, sedangkan untuk produk susu, variasi lain dari olahan susu yang dibuat hanya berupa yoghurt.

Dengan adanya potensi tersebut, jika dikembangkan menambah ragam pilihan produk makanan sebagai salah satu produk wisata yang ditawarkan sehingga dapat meningkatkan kesesuaian produk wisata yang ditawarkan dengan permintaan wisatawan yang bersifat heterogen dikarenakan latar belakang wisatawan yang berbeda-beda dengan tidak melepaskan nilai autentitas atau identitas dari produk makanan yang ditawarkan.

\section{Tinjauan Mengenai Pie Susu}

Pie merupakan crust (kulit pie) yang mengandung isian, baik manis atau asin, lalu dibakar. Pie bisa memiliki penutup yang terbuat dari crust pada bagian atas atau juga tidak ditutup. Pie berasal dari bangsa Mesir, kemudian berkembang ke benua Eropa hingga menjadi salah satu makanan tradisional bangsa Amerika (Rinsky\&Rinsky, 2009).
Biasanya pie berbentuk bundar dengan sisi yang menjorok sehingga bagian bawah memiliki diameter yang lebih kecil dibanding dengan diameter bagian atas.

Jenis-jenis adonan untuk membuat kulit pie ditentukan dengan jenih bahan baku yang digunakan, proporsi dari bahan baku yang diugnakan, bagaimanan cara pencampuran lemak serta bagaimana adonan kulit pie diuleni. Untuk jenis pie yang akan disajikan langsung serta ditutup menggunakan jenis kulit pie yang bersifat flaky (sangat rapuh) dan mealy (mudah rapuh). Untuk mendapatkan kulit pie yang rapuh maka menggunakan lemak beku yang dipotongpotng kasar sebelum dicampurkan dengan tepung untuk meminimalisir pembentukan gluten, sehingga struktur pie tidak terbentuk maksimal dan menghasilkan kulit yang rapuh.

Gluten adalah protein yang tidak larut dalam air yang terbentuk apabila tepung terigu yang telah dicampur dengan air mengalami proses pengadukan. Gluten sangat berperan dalam pembentukan struktur produk makanan. Namun untuk jenis pie yang dikeluarkan dari tempatnya serta memiliki isian yang memerlukan kulit pie yang kuat maka diperlukan kulit pie yang lebih kuat yang disebut dengan sweet tart dough (Pate Sucree) (labensky, dkk., 2016). Jenis kulit pie ini didapat dari lemak yang dicampur secara merata dengan tepung kemudian ditambahkan telur sehingga adonan lebih mengembang dan lebih lembut. Kemudian menggunakan gula tepung untuk menghasilkan tekstur remah yang tidak kasar. Dengan demikian, karena jumlah lemak yang dicampur lebih banyak, dengan adanya tambahan telur, maka jenis tepung yang digunakan pun merupakan tepung protein sedang. Kemudian teknik pengadukan juga tetap diminimalisir, untuk mencegah terjadinya pembentukan gluten yang terlalu matang..

Sementara itu pie susu atau egg tart terkenal sebagai makanan khas dari kota Hong Kong. Tidak ada sejarah pasti asal muasal dari Hong Kong egg tart, namun ada beberapa spekulasi yang berpendapat bahwa Hong Kong egg tart berasal dari British custard egg tart karena pada masa tersebut Hong Kong dikoloni oleh Negara Inggris, namun pendapat lain menyatakan bahwa makanan tersebut berasal dari Portugis 
karena pada masa penjajahan Macau (yang merupakan kota tetangga Hong Kong) sedang dikoloni oleh bangsa Portugis (Vijaya, 2016). Lebih lanjut lagi, egg tart sudah ada di Hong Kong sejak tahun 1940-an, dan pada tahun 2011 termasuk ke dalam 50 makanan paling enak di dunia menurut CNN (tanpa nama, 2017).

Di Indonesia, pie susu merupakan oleholeh khas dari kota bali, berbentuk bundar berdiameter $7 \mathrm{~cm}$, kulit pie memiliki karakteristik tipis dan renyah, dengan isian berupa egg custard yang tidak terlalu banyak atau tebal, lembut dan dengan tekstur luar yang kering. Kemudian, rasa yang muncul ketika mengkonsumsi pie ini adalah rasa manis yang dominan dengan sedikit aroma vanilla. Pie susu mulai berkembang sebagai oleh-oleh khas Bali setelah diproduksi di rumahan sejak tahun 1989 di Jalan Nangka, Denpasar, Bali. Hingga saat ini sudah tersedia berbagai varian pie susu dengan merek yang berbeda-beda. Rasa original merupakan rasa asli telur dan susu, serta manis, sementara variannya dapat ditemui dari rasa coklat, keju, hingga kopi (Hikmah, 2014). Dengan demikian, dari resep dasar pie susu tersebut dapat dikombinasikan dengan rasa lainnya untuk menciptakan varian yang berbeda.

\section{Tinjauan Mengenai Tepung Ubi Jalar}

Studi mengenai ubi jalar sebagai potensi alternative sumber karbohidrat di Indonesia mulai mendapatkan perhatian lebih beberapa tahun ini. Hal ini berkaitan dengan misi Negara Indonesia untuk mencapai ketahanan pangan nasional dengan tidak bergantung kepada produk-produk impor terutama tepung terigu yang bukan berasal dari Indonesia. Beberapa riset telah dilakukan untuk mengetahui kemampuan tepung ubi jalar dalam menghasilkan variasi makanan, dan kemudian diketahui bahwa tepung ubi jalar memiliki kandungan pati yang dapat digunakan sebagai bahan baku utama ataupun partial dalam pembuatan kue kering, kue, roti, makanan bayi, mie dan lainnya (Kelana, 2017). Berikut adalah perbandingan komposisi kimia dari tepung terigu dan tepung ubi jalar:

\section{PERBANDINGAN KOMPOSISI KIMIA TEPUNG UBI JALAR DAN TEPUNG TERIGU}

\begin{tabular}{|l|c|c|}
\hline \multirow{2}{*}{$\begin{array}{c}\text { Komposisi } \\
\text { Kimia (\%) }\end{array}$} & $\begin{array}{c}|c| \\
\text { Tepung Ubi } \\
\text { jalar }\end{array}$ & $\begin{array}{c}\text { Tepung } \\
\text { Terigu }\end{array}$ \\
\hline Air & 7.00 & 14.5 \\
\hline Protein & 5.12 & 8.90 \\
\hline Lemak & 0.5 & 1.30 \\
\hline Abu & 2.13 & 0.25 \\
\hline Karbohidrat & 85.26 & 77.30 \\
\hline Serat & 1.95 & 0.4 \\
\hline $\begin{array}{l}\text { Kalori } \\
\text { (cal/100gr) }\end{array}$ & 366.89 & 365.00 \\
\hline
\end{tabular}

Sumber: Widjanarko, 2008 dalam Yuwono, 2015 dan Direktorat Gizi, Depkes RI (1996)

Berdasarkan tabel tersebut tepung ubi jalar memiliki jumlah serat yag lebih banyak dengan jumlah kalori hampir menyamai tepung terigu. Namun, protein yang dihasilkan tidak memadai bagi anak-anak yang sedang mengalami masa tumbuh kembang (Santosa dkk., 2016). Akan teatapi, masih banyak kandungan pada ubi jalar lainnya yang sangat bermanfaat bagi tubuh bila dibandingkan dengan terigu, seperti vitamin $\mathrm{C}$, vitamin $\mathrm{B} 6$ kemudian fosfor, kalsium, mangan, zat besi, betakrotin yang baik untuk pencernaan serta memiliki indeks glikemik yang rendah. Kemudian, ubi jalar yang memiliki warna memiliki kandungan antioksidan yang berfunsgi untuk membersihkan radikal bebas, begitu juga dengan ubi jalar ungu dimana perbedaannya terletak dari kandungan antosianin yang berfungsi sebagai senyawa antioksidan. Ubi jalar yang ada di Indonesi terdiri dari ubi jalar putih, kuning, merah, oranye dan ubi jalar ungu.

Ubi jalar atau disebut juga ketela rambat dengan nama latin Ipomoea batatas $\mathrm{L}$. kurang diminati oleh masyarakat dikarenakan identic dengan makanan kampung, dibandingkan dengan tepung terigu dan olahannya yang diminati oleh seluruh kalangan masyarakat. Oleh karena itu diperlukan inovasi dalam pemanfatan ubi jalar untuk dapat bersaing dengan produk olahan tepung terigu sebagai upaya untuk mendukung pemerintah dalam melaksakan Peraturan Presiden no. 22 tahun 2009 mengenai kebijakan Percepatan Penganekaragaman Konsumsi Pangan 
Berbasis Sumber Daya Lokal demi menciptakan ketahanan pangan nasional (Susetyo dkk., 2016). Saat ini tepung ubi jalar sudah digunakan dalam pembuatan kue, cookies, roti, mie, es krim, pancake dan lainnya. Warna tepung yang dihasilkan akan mengikuti warna dasar dari jenis ubi jalar yang digunakan, namun jika menggunakan tepung ubi jalar yang tidak dikukus terlebih dahulu akan meninggalkan sedikit rasa pahit bila dibandingkan dengan tepung ubi jalar matang.

Sentra ubi jalar di Kabupaten Bandung berada di Kecamatan Arjasari, Cimaung, Cicalengka, Cikancung dan Pasir Jambu. Ubi jalar ditanam pada ketinggian 500 mdpl namun bisa juga sampai dengan ketinggian 1000 mdpl dengan suhu $21-27^{\circ} \mathrm{C}$, di daerah tropis dengan curah hujan 750-1500 $\mathrm{mm} /$ tahun. Agar dapat tumbuh dengan baik maka diperlukan 11-12 jam sinar matahari dan dapat tumbuh di tegalan sawah. Meskipun tidak dibudidayakan di desa Alamendah, namun pemanfaatanya dapat membantu pengembangan desa lainnya yang juga berada di wilayah Kabupaten Bandung.

\section{Tinjauan Mengenai Susu Evaporasi}

Susu yang digunakan adalah susu yang berasal dari sapi. Merupakan kombinasi alami dari air, protein, mineral, laktosa, vitamin, padatan susu dan lemak susu. Biasanya diklasifikasikan berdasarkan kandungan lemak susunya. Susu adalah salah satu bahan yang penting dalam pembuatan produk pastry dan bakery. Kemudian, fungsi susu dalam pembuatan produk pastry dan bakery adalah untuk meningkatkan warna dan kelembutan dari kulit makanan, meningkatkan daya tahan simpan, menghasilkan remah yang rata dan lembut, menambah rasa, memberikan aroma, menyerap dan memberikan kelembaban, membantu proses koagulasi pada telur serta meningkatkan nilai gizi dari makanan.

Jenis susu yang digunakan dalam pembuatan pie susu adalah evaporated milk yaitu susu yang sudah dihilangkan kadar airnya sebanyak 60\%. Walaupun tidak ditambahkan gula dalam pembuatannya, namun susu evaporated memiliki rasa seperti caramel dikarenakan lactose yang terkaramelisasi pada saat proses evaporasi berlangsung. Dengan demikian, karakteristik dari susu evaporated selain ada sedikit rasa manis, karena sudah terevaporas, konsistensi dari susu evaporated lebih kental dari susu biasanya, mengandung lebih banyak cream serta berwarna sedikit kecoklatan. Laktosa merupakan kelompok disakarida terdiri dari glukosa dan galaktosa. Laktosa merupakan kandungan dari susu atau disebut sebagai gula susu. Dalam tubuh manusia, ketika mengkonsumsi susu, enzim lactase yang ada didalam tubuh akan memecah laktosa menjadi glukosa dan galaktosa sehingga karbohidrat ini dapat diserap oleh tubuh.

Susu yang dievaporasi sebaiknya merupakan susu yang sudah melalui proses homogenisasi, agar cream susu tidak terpisah dari kandungan cairan lainnya. Untuk mencegah kontaminasi, sebaikanya mengkonsumsi susu yang sudah dipasteurisasi dengan tujuan menghilangkan bakteri pathogen penyebah timbulnya penyakit. Susu yang dipasteurisasi adalah susu segar yang dipanaskan pada sushu $72^{\circ} \mathrm{C}$ dengen waktu pemanasan minimal adalah 15 menit atau yang dikenal dengan HTST atau high-temperature, short-time.

Untuk memdapatkan susu evaporated caranya sangat mudah yaitu dengan mendidihkan susu menggunakan api kcil hingga jumlah susu menjadi setengah dari jumlah awal. Dengan demikian jika yang dibutuhkan adalah susu cair biasa, maka bisa dengan menambahkan air pada susu evaporated dengan perbandingan 1:1 (Figoni, 2011). Meskipun harga pasar dari susu evaporated lebih mahal dibanding dengan susu cair biasa, ada beberapa keuntungan yang didapat. Diantaranya adalah karena susu evaporated mengandung lebih banyak cream dengan jumlah yang lebih sedikit, maka dapat mengurangi tempat penyimpanan, sementara itu untuk susu evaporated yang kalengan, memiliki day simpan yang lama pada suhu ruangan bila dibandingkan dengan susu cair biasa selama tidak dibuka, kemudian dalam pembuatan isian pie pada custard akan menghasilkan isin yang lebih tebal, lembut dan creamy, sehingga lebih legit, dan jika ada produk yang membutuhkan cream dengan jumlah lemak yang rendah maka dapat menggunakan susu evaporasi.

\section{Tinjauan Mengenai Bandrek}

Bandrek adalah salah satu jenis minuman yang disajikan dan dikonsumsi dalam kondisi 
hangat atau yang disebut dengan wedang (Dewi, 2017). Bandrek merupakan minuman yang terbuat dari bahan dasar utama yaitu jahe dan ditambahkan dengan rempahrempah seperti cengkeh, pala, gula aren, lada hitam dan rempah lainnya. Terkadang ditambahkan dengan cabe, parutan daging kelapa serta susu. Oleh karena itu, minuman yang berasal dari tanah Sunda, Jawa Barat ini memiliki karakteristik manis dan pedas, memiliki aroma rempah serta berwarna coklat keruh serta gurih legit bila ditambahkan dengan daging kelapa.

Minuman ini berkaitan erat dengan kejayaan rempah di masa lampau, dimana pada saat rempah-rempah adalah bahan baku yang hanya terdapat di negara Indonesia, sehingga orang-orang Eropa pada jaman dahulu melakukan sistem barter untuk mendaptkan rempah-rempah langka tersebut dengan barang-barang berharga milik mereka seperti senjata (Widadio, 2014). Namun, seiring dengan ditemukannya gula, macammacam varietas kopi serta teh, populritas minuman rempah menjadi kurang popular dimulai sejak abad 19-20. Oleh Karena itu, agar tidak tersingkirkan, minuman ini sudah dapat ditemukan dalam berbagai bentuk, dari mulai bentuk pasta bandrek dasar yang perlu dicampur kembali dengan air, kemudian dalam botol yang siap saji serta dalam bentuk sachet atau bandrek instan agar mudah ditemukan dimana saja dan mampu menjangkau masyarakat luas.

Minuman ini sekarang tidak hanya dapat dinikmati di tanah Sunda saja, namun dapat ditemukan dimana-mana. Selain itu, bandrek juga dimodifikasi dengan dicampurkan dengan bahan-bahan lain seperti kopi dan durian, serta dibuat dalam bentuk lain seperti es krim bandrek.

Bandrek bersamaan dengan bajigur merupakan minuman yang sangat popular di Jawa Barat (Suceno, 2014). Berbeda dengan bandrek, bajigur memiliki tambahan santan dan memiliki rasa yang tidak terlalu kuat karena tidak mengandung rempah-rempah sebanyak bandrek. Bandrek diminum ditempat yang berhawa dingin karena kndungan jahe didalamnya yang memiliki senyawa zingeron memberikan sensasi hangat bagi tubuh. Dengan tambahan rempah lainnya bandrek memiliki manfaat diantaranya adalah menurunkan tekanan darah, mencegah perut kembung, mengatasi masuk angin, mencegah tersumbatnya pembuluh darah, mengobati rematik dan pegal linu, mencegah jerawat, mempercantik kulit, menjaga daya tahan tubuh dan lainnya. Oleh karena itu, bandrek dikenal juga sebagai minuman herbal. Cara membuat bandrek sangatlah mudah, yaitu dengan cara merebus semua bahan hingga aroma dari jahe dan rempah-rempah lainnya tercium. Tidak ada waktu khusus dalam mengkonsumsi bandrek. Biasanya bandrek disajikan dengan makanan rebus seperti kacang rebus, ubi rebus, singkong rebus dan lainnya sebagai makanan kudapan.

Di luar negeri alcohol dikonsumsi untuk menghangatkan tubuh, maka dengan variasi bentuk bandrek yang mudah didapat, memberikan potensi bagi bandrek untuk dapat dikenal di mancanegera sebagai alternative minuman yang juga dapat menghangatkan tubuh namun juga menyehatkan. Namun yang perlu diperhatikan adalah untuk tetap menjaga kekhasan dari minuman bandrek itu sendiri yaitu rasa dominan jahe dan gula aren, yang dicampur dengan rempah-rempah asli Indonesia. Berdasarkan asal muasal minuman bandrek tersebut, bandrek seharusnya menjadi minuman tradisional kebanggaan negara Indonesia untuk dapat merepresentasikan keanekragaman makanan negara Indonesia yang kaya akan rempah-rempahnya.

\section{METODE}

Penelitian ini menggunakan metode eksperimen dengan menggunakan pendekatan kuantitatif. Metode eksperimen dilakukan apabila peneliti akan memanipulasi satu variable atau lebih, dengan satu atau beberapa kelompok control dan kemudian mengukur dan menganalisa perbedaan yang terjadi. Tujuan dari metode ini adalah untuk mempelajari hubungan sebab akibat. Dengan demikian dalam penlitian ini, pie susu merupakan kelompok control yang tidak dimanipulasi oleh peneliti, sementara maipulasi dilakukan dengan mengganti dan menambahkan bahan baku dari pie susu, dan kemudian dilakuan observasi untuk mengukur perbedaan yang dihasilkan, mendeskripsikannya dan kemudian dipelajari apakah penggantian bawhan baku tersebut memberikan perbedaan yang signifikan bila 
dibandingkan dengan kelompok control (Sugiyono, 2013).

Jenis metode eksperimen yang digunakan adalah true eksperimen karena memiliki kelompok control serta pengambilan sampel dilakukan secara acak, dengan desain eksperimen berupa posttest-only control group design, dimana pengukuran dilakukan setelah perlakuan diberikan. Penelitian ini akan menghasilkan empat produk yang akan diujikan, yaitu produk A atau produk control, pie susu yang terbuat dari tepung terigu dan susu evaporated komersial, kemudian produk B yaitu pie susu bandrek yang terbuat dari tepung ubi oranye dengan filling bandrek yang terbuat dari susu murni lokal. Begitu pula dengan produk $C$ dan $D$, sama seperti produk $\mathrm{B}$ yang berbeda hanyalah jenis tepung ubi yang digunakan yaitu produk $\mathrm{C}$ memakai tepung ubi ungu dan produk D menggunakan tepung ubi putih.

Penulis menggunakan uji sensori untuk mendapatkan data primer, yaitu uji yang dilakukan untuk mengevaluai suatu produk makanan berdasarkan panca indra yang dimiliki oleh manusia (Svensson, 2012). Data yang bersifat naratif akan didapat dari hasil wawancara mengenai profile sensori dari produk eksperimen terhadap panelis, terdiri dari tiga aspek yaitu aspek tampilan, teksture dan flavor. Menurut Suradi (2007) dalam Irianti (tanpa tahun, par.1) arti panelis dalam uji sensori "adalah sekelompok orang yang bertugas menilai sifat atau kualitas bahan berdasarkan kesan subyektif". Wawancara ini akan dilakukan terhadap 15 panelis terlatih, merupakan panelis yang diseleksi dan melalui serangkaian latihanlatihan sehingga dapat menilai beberapa sifat rangsangan yang berkaitan dengan panca indra. Kemudian, teknik pengukuran data yang dilakukan adalah dengan melakukan uji hedonik atau uji penerimaan atau uji kesukaan yang akan dilakukan terhadap 50 panelis tidak ahli untuk mengetahui apakah produk eksperimen dapat diterima oleh masyarakat.

Untuk data narasi yang didapat dari hasil wawancara maka akan dilakukan teknik analisi deskriptif kualitatif, yaitu dengan menjabarkan, kemudian menelaah serta memberikan argunmentasi dari data yang didapat. Sementara itu, untuk menganalisis data yang didapat dari uji hedonik maka akan dilakukan uji signifikansi untuk melihat perbedaan yang ada diantara perlakuan yang diberikan. Jika berbeda, maka H1 terbukti, dimana ada perbedaan dari perlakuan yang diberikan. Jika tidak ada perbedaan, maka HO berlaku. Kemudian akan dilakukan analisis lanjutan yaitu uji Friedman untuk mengetahui rata-rata ranking dari perlakuan yang diberikan, kemudian dilanjutkan dengan anailsa statistic deskriptif, yaitu analisa yang hanya mendeskripsikan hasil perhitungan dan mengambil kesimpulan dari hasil tersebut namun tidak dapat diberlakukan secara umum (Iran \&Siti, 2015).

\section{HASIL DAN PEMBAHASAN}

Hasil observasi penulis serta uji sensori pada panelis terlatih memberikan hasil yang serupa, dimana bentuk dari produk A memiliki proporsi yang baik, dengan permukaan kulit dan isian yang halus dan terlihat lembut. Tekstur dari kulit pie seragam, namun isian terlihat kering dan kurang lembab, hal ini dikarenakan proporsi isian yang sedikit, sehingga rentan terhadap panas oven. Oleh karena itu diperlukan suhu oven yang stabil dan merata. Selain itu, kulit pie juga dianggap sedikit pucat, apabila dibandingkan dengan warna dari isian. Warna dari tepung terigu tidak memberikan efek apapun pada produk yang dihasilkan selain dari warna kecoklatan yang dihasilkan dari proses pati dan gula adonan yang bereaksi dengan panas oven. Tekstur rapuh yang terlihat dikarenakan penggunaan tepung terigu protein rendah serta metode rub-in yang digunakan, sehingga jaringan gluten yang terbentuk tidak optimal menghasilkan remahan yang terlihat pada kulit pie.

Sementara itu, produk B yaitu produk yang menggunakan tepung ubi oranye, memberikan warna kulit yang lebih cerah, hal ini disebabkan dari pencampuran $60 \%$ tepung ubi oranye dengan $40 \%$ tepung terigu, tekstur yang terlihat pun lembut dan rapuh, sementara isian bandrek yang diberikan setelah dipanggang tidak mengalami perubahan warna, tetap berwarna gelap seperti bandrek. Kemudian, isian juga terlihat sangat lembab dan tidak rata, karena tingkat kekentalan filing bandrek berbeda dengan isian susu pada produk $\mathrm{A}$, dengan kandungan gula yang lebih tinggi, sehingga kilauan yang dihasilkan mudah terlihat. Selain itu juga 
terdapat lubang-lubang kecil sebagai akibat kandungan bandrek yang tidak mudah untuk menyatu dengan adonan dari susu dan telur. Kemudian, panelis terlatih berpendapat bahwa warna kulit yang dihasilkan terlihat sangat cerah apabila terpapar cahaya, dimana warna oranye dari kulit seperti bercampur warna coklat muda. Panelis terlatih juga memiliki pendapat yang sama mengenai tekstur kulit yang terlihat seragam dan rapuh, serta isian yang terkesan basah.

Berikutnya adalah produk C dimana tepung yang digunakan adalah tepung ubi ungu. Tekstur dari kulit pie yang didapat terlihat lebih padat dan tidak seragam. Pencampuran $60 \%$ tepung ubi ungu dengan $40 \%$ tepung terigu mampu menghasilkan adonan kulit yang bisa dibentuk, namun setelah dibakar tidak merubah warna kulit yang tetap berwarna gelap mendekati warna coklat yang keungu-unguan. Pada saat proses pembuatan adonan, diperlukan lebih banyak cairan untuk mendapatkan konsistensi adonan yang pas, karena ubi ungu memiliki jumlah pati yang lebih banyak dengan kandungan air yang lebih sedikit. Ketidakseragam tekstur dan warna terlihat dari bintik-bintik putih yang berasal dari pencampuran kedua tepung tersebut. Walaupun bentuk yang dihasilkan masih memiliki proporsi yang baik. Isian bandrek yang diberikan terlihat lebih gelap dan sangat lembab, selain warna yang terlihat, karakteristik isian lainnya terlihat sama dengan produk $\mathrm{B}$, dimana kilauan mudah terlihat dan terdapat lubang-lubang kecil pada permukaan isian. Dengan warna dan tampilan yang dihasilkan, panelis terlatih berpendapat membuat isian seperti basah dan belum matang, sementara itu perpaduan warna yang diberikan kurang menarik selera, terutama dengan bintik-bintik putih yang sangat terlihat pada kulit pie.

Perpaduan warna dengan kontras yang baik dihasilkan oleh produk $\mathrm{D}$, yaitu produk yang menggunakan $60 \%$ tepung ubi putih dan $40 \%$ terigu. Walaupun berasa dari ubi putih, namun karakteristik tepung yang dihasilkan berwarna sedikit coklat, hal tersebut berdampak terhadap kulit pie yang dihasilkan setelah proses pemanggangan. Warna dari kulit pie, yaitu coklat muda, sehingga lebih cocok untuk gabungkan dengan isian bandrek. Tampilan kulit juga terlihat tidak terlalu padat dan rapuh, dengan tekstur yang terlihat renyah, bintik-bintik putih yang terlihat pada kulit tidak begitu kentara bila dibandingkan dengan produk C. Sementara itu, karakteristik isian yang ditemukan hampir sama dengan produk B dan C, dimana isian terlihat lembap, berkilau, berwarna gelap serta tidak rata dengan lubang-lubang kecil dibagian permukaan. Panelis terlatih juga berpendapat bahwa perpaduan warna yang diberikan merupakan yang paling baik diantara produk-produk lainnya. Memiliki bentuk dengan proporsi yang bagus serta terlihat tidak terlalu padat. Kesan rapuh masih terlihat pada kulit yang dihasilkan. Isian bandrek yang diberikan terlihat tidak terlalu gelap, namun kesan lembab masih terlihat.

Sementara itu, hasil uji hedonik menunjukkan bahwa produk A yang merupakan produk kontrol memiliki rata-rata peringkat (mean rank) yang paling tinggi, diikuti dengan produk D yaitu pie susu bandrek dengan menggunakan tepung ubi putih, kemudian produk B yaitu pie susu bandrek yang menggunakan tepung ubi oranye, dan terakhir adalah produk D yang menggunakan tepung ubi ungu. Berdasarkan rata-rata (mean) yang terdapat pada table statistic descriptive diketahui bahwa produk A memiliki rata-rata tertinggi untuk aspek tampilan yaitu 7.14 dengan pembulatan 7 dimana pada 9 poin skala hedonic berarti responden menyukai produk tersebut, begitu pula dengan produk $\mathrm{D}$ yang menempati urutan kedua secara ranking yaitu rata-rata 6.70 dengan pembulatan 7. Sementara itu, produk C memiliki rata-rata 5.60 dengan pembulatan 6 merupakan produk yang cukup disukai oleh responden. Dan produk D, dengan rata-rata 4.40 dan pembulatan 4 merupakan produk kurang disukai oleh responden.

Tekstur yang dihasilkan juga bergantung kepada jenis tepung yang digunakan terutama dengan ada tidaknya kandungan gluten, jumlah pati yang dimiliki, tingkat kelembapan tepung serta karakteristik isian. Berdasarkan hasil observasi, tekstur kulit yang dimiliki oleh produk A terasa kering saat menyentuh mulut, kemudian ringan dan rapuh sehingga mudah untuk dikunyah. Tekstur yang kering namun rapuh juga terasa ketika disentuh. Kandungan gluten yang sesuai dengan jumlah pati yang pas serta 
metode pembuatan yang benar membuat kulit memiliki tekstur yang baik. Sementara itu, tekstur isian terasa sedikit lembap didalam, dengan permukaan yang kering. Paduan kedua jenis tekstur ini menghasilkan pie susu yang mudah untuk dikunyah dan mudah untuk ditelan. Panelis terlatih pun memiliki pendapat yang sama, yaitu tekstur pie pada umumnya yang lembut, kering dan rapuh.

Kemudian, tekstur B dan D memiliki karakteristik yang tidak terlalu berbeda. Berdasarkan hasil observasi kulit yang dihasilkan terasa lebih padat namun kering dan crunchy ketika digigit dan dikunyah. Menurut panelis terlatih, walaupun lebih padat namun masih memiliki sifat renyah dan sedikit rapuh. Dengan adanya penambahan tepung terigu membuat kulit memiliki tekstur yang lentur dan berstruktur. Sementara itu, isian bandrek yang diberikan sangat lembap dan chewy, mirip dengan pudding. Akan tetapi, saat dikunyah bersamaan, mudah untuk hancur dan dapat ditelan dengan mudah.

Sementara itu untuk produk C, berdasarkan hasil observasi dan uji sensori panelis terlatih, memiliki tekstur yang paling padat dan lebih lembab namun keras pada bagian luar. Sehingga tekstur yang didapat pada saat dikunyah tidak crunchy atau renyah. Karena tepung ubi ungu memiliki kadar air yang lebih sedikit serta jumlah pati yang lebih banyak sehingga daya serap terhadap cairan pun tinggi, dan diperlukan jumlah telur yang lebih banyak ketika proses pembuatan adonan, sehingga kulit yang dihasilkan lebih padat dan lembap. Sementara itu tekstur dari isian bandrek yang didapat tidak jauh berbeda dengan produk B dan D, namun ketika kedua tekstur tersebut dipadankan, membutuhkan waktu yang lebih lama untuk dapat dikunyah, pie tidak langsung hancur pada saat dikunyah.

Uji hedonik menunjukkan bahwa berdasarkan rata-rata, produk A adalah produk yang yang disukai oleh responden, begitu juga dengan produk $\mathrm{D}$, dengan pembulatan 6.64 menjadi 7 produk tersebut disukai. Sementara itu produk B menempati urutan ketiga sebagai produk yang cukup disukai dan terakhir adalah produk C, walaupun dengan nila rata-rata yang lebih kecil, akan tetapi dengan pembulatan 5.66 menjadi 6, produk tersebut cukup disukai oleh masyarakat.

Selanjutnya adalah aspek flavor terdiri dari tiga komponen penyusun, yaitu rasa dasar, aroma dan trigeminal effect. Berdasarkan hasil observasi dan juga profil sensori yang dirangkum dari panelis terlatih diketahui bahwa produk A memiliki aroma campuran vanilla dan telur, dimana padanan aroma ini mampu menggugah selera responden untuk mencicipi. Aroma tersebut merupakan aroma standar yang ditemui pada pie umumnya, walaupun aroma mentega tidak terlalu tercium, namun aroma tersebut sangat dikenal di masyarakat. Sementara itu, rasa dasar yang didapat ketika dikunyah adalah rasa gurih manis yang berasal dari kulit yang menggunakan mentega serta isian susu yang manis. Aftertaste atau trigeminal effect yang terasa hanya sedikit rasa manis yang tertinggal di lidah.

Kemudian, sangat berbeda dengan produk A, produk B, C, dan D memiliki aroma dominan jahe dan rempah-rempah. Namun tidak seperti produk A dimana aroma yang ditangkap mampu menggugah selera responden, aroma jahe dan rempah-rempah ini tidak begitu menggugah selera. Akan tetapi pada roduk $\mathrm{D}$ ada aroma lain yang juga terdeteksi kuat, yaitu aroma dari tepung ubi. Sementara, walaupun produk B dan D menggunakan tepung ubi, namun aroma ubi yang tercium tidak terlalu kuat. Begitupun dengan rasa yang didapat. Produk B dan produk D menghasilkan rasa yang mirip, namun padanan rasa dianggap lebih cocok pada produk D. Rasa ubi sedikit terasa menyatu dengan rasa jahe yang memberikan aftertaste atau sensai hangat setelah dikunyah. Untuk beberapa panelis, rasa hangat tersebut terasa seperti rasa pedas. Rasa yang dihasilkan disebut sebagai rasa unik yang baru. Produk D dianggap memberikan sedikit rasa gurih sehingga produk D lebih enak dibanding dengan produk B. Hal ini dikarenakan rasa dari tepung ubi putih yang tidak terlalu manis bila dibandingkan dengan tepung ubi putih, sehingga kulit pie pada produk D mampu menyerap kontribusi rasa gurih dari mentega, seperti pada produk A.

Namun, pada produk D, selain aroma ubi yang terasa lebih kuat, rasa dari kulit yang dihasilkan juga lebih manis, sehingga bila 
padankan dengan rasa dari isian bandrek membuat produk menjadi terlalu manis. Selain itu, padanan tersebut juga menimbulkan aftertaste yang selain sensasi rasa hangat tapi juga sedikit pahit. Selanjutnya, untuk mengetahui daya terima masyarakat terhadap aspek flavor, aspek yang dinilai hanyalah rasa dan aroma, sementara utuk profil sensori panelis terlatih juga diminta untuk memberikan pendapat mengenai trigeminal effect. Hal ini disebabkan tingkat kepekaan panelis terlatih terhadap rasa yang dihasilkan. Dari nilai rata-rata keseluruh flavor diketahui bahwa ada sedikit perbedaan rata-rata antara produk A dan produk $\mathrm{D}$, namun dengan pembulatan kedua produk tersebut berada pada pada satu deskripsi skala yang sama yaitu sama-sama disukai oleh responden. Kemudian produk ketiga yaitu produk B dengan pembulatan dari 5.91 ke 6 merupakan produk yang cukup disukai dari aspek flavor. Sementara produk C dianggap memiliki flavor yang biasa saja dengan pembulatan dari 5.39 ke 5 .

Tepung ubi sendiri tidak dapat digunakan sebagai pengganti tepung terigu dalam pembuatan kulit pie sebesar $100 \%$, hal ini dikarenakan tepung ubi tidak memiliki protein pembentuk gluten sehingga tidak mampu membentuk struktur dan tekstur remah yang renyah dan rapuh seperti kulit pie pada umumnya. Kulit pie yang dihasilkan cenderung lebih padat karena kandungan pati yang banyak. Namun dengan kandungan gizi yang terkandung didalamnya, tepung ubi mampu meningkatkan nilai gizi dari kulit pie yang dihasilkan dibandingkan dengan dengan kulit pie yang hanya terbuat dari tepung terigu. Selain itu, rasa dan aroma yang dihasilkan juga unik dan terasa lebih legit. Sementara itu, isian bandrek yang digunakan memiliki kesesuaian rasa dengan kulit pie yang terbuat dari tepung ubi, karena pada umumnya ketika mengkonsumsi bandrek makan pendamping yang biasa disajikan adalah ubi rebus. Hanya saja tidak semua bagian dari masyarakat menyukai rasa bandrek pada level yang sama, terutama dengan jenis bandrek yang digunakan oleh penulis, oleh karena itu diperlukan formula bandrek khusus yang dapat disukai oleh seluruh bagian masyarakat.

\section{SIMPULAN}

Melalui hasil pembahasan yang telah diuraikan sebelumnya, maka dapat disimpulkan bahwa tampilan dari pie susu bandrek memiliki tampilan yang berbeda dengan produk A atau produk control, yaitu warna kulit pie yang mengikuti warna tepung ubi ynag digunakan, warna isian yang gelap, memiliki kilauan, serta tektur yang terlihat lebih padat dibandingkan dengan tampilan pada produk A. Namun dari produk-produk tersebut selain tampilan produk A yang disukai tampilan dari produk D atau pie susu bandrek yang menggunakan tepung ubi putih juga disukai dan dapat diterima oleh masyarakat karena padanan warna yang dianggap sesuai dibandingkan dengan produk B dan C. Selanjutnya, tekstur yang dihasilkan dari pie susu bandrek juga memiliki perbedaan dengan produk A. tekstur yang dihasilkan lebih padat, tidak terlalu rapuh, lebih kering dengan tekstur isian yang basah seperti pudding.

Seperti halnya tampilan, produk A dan D adalah produk yang disukai oleh masyarakat, walaupun lebih padat, namun kulit pie masih tidak sepadat produk D dan memiliki kerenyahan yang sesuai dengan isian bandrek yang digunakan.Kemudian, flavor dari produk A dan D juga disukai oleh masyarakat bila dibandingkan dengan produk B dan C. Berbeda dengan produk A yang sudah umum dikenal oleh masyarakat, rasa uni yang dihasilkan oleh produk $\mathrm{D}$ juga ternyata disukai oleh responden.

Dengan demikian dari ketiga aspek tersebut maka dapat disimpulkan bahwa produk D atau pie susu bandrek yang menggunakan tepung ubi putih adalah pie susu bandrek yang paling disukai dibandingkan dengan pie susu bandrek yang terbuat dari tepung ubi oranye (produk B) dan pie susu bandrek yang terbuat dari tepung ubi ungu (produk D). Dengan daya terima yang baik, maka tepung ubi putih dapat digunakan sebagai pengganti sebagian tepung terigu dalam pembuatan kulit pie dengan proporsi ideal sebesar 60\%, sehingga pie susu bandrek yang dihasilkan merupakan varian baru yang dapat dijadikan varian oleh-oleh produk makanan di desa Alamendah, Ciwidey, Kab. Bandung.

Namun, diperlukan penelitian lanjutan untuk memeperbaiki tampilan agar terlihat lebih menarik seperti menambahkan garnish 
mengingat warna isian yang gelap, seperti penambahan kelapa parut kering, gula palm suiker, atau yang lainnya.

Sementara itu, untuk segi tekstur, tekstur yang dianggap kurang baik adalah tekstur isian yang masih basah, oleh karena itu diperlukan peneltiian lanjutan untuk mengganti bandrek yang digunakan dengan formula bandrek tersendiri.Kemudian, rasa dan aroma rempah yang unik merupakan daya tarik dari pie susu bandrek yang dihasilkan, namun ada beberapa responden yang tidak cocok dengan aftertaste berupa sensai hangat atau pedas yang dihasilkan, oleh karena itu dengan formula bandrek yang disesuaikan maka dapat selain memperbaiki tekstur juga dapat memperbaiki rasa yang dihasilkan tanpa mengurangi aroma rempah yang dianggap unik oleh responden. Dan, penelitian lanjutan mengenai daya tahan dari pie susu bandrek yang dihasilkan sangat dianjurkan, apabila pie susu bandrek tersebut akan dijual dan dikonsumsi secara komersil.

\section{DAFTAR PUSTAKA}

Anonymous. (2017). Intip Sejarah Egg Tart yang Sedang Hits di Indonesia. Diakses pada 24 Juli 2018 pada: https://pergikuliner.com/blog/intipsejarah-egg-tart-yang-sedang-hits-diindonesia

Dewi, S. (2017). 8 Wedang atau Minuman Hangat dari Jahe Khas Indonesia. Diakses pada 24 Juli 2018 pada: https://resepkoki.id/2017/07/26/8wedang-atau-minuman-hangat-darijahe-khas-indonesia/

Elgad, M., et al. (2017). Optimalisasi Promosi Produk Wisata Desa Alamendah, Provinsi Jawa Barat. Laporan Kuliah Kerja Nyata Program Pemberdayaan Masyarakat (KKN-PPM) STP Bandung Tahun Akademik 2016/2017. Diakses pada 24 Juli 2018 pada: https://drive.google.com/file/d/1n84r UmolBLTFGTGSsJesr3N90Rryr9XQ/vie $\underline{\mathrm{w}}$

Irianti, M.A.D. (n.d). Panelis adalah Sekelompok Orang yang Bertugas Menilai Sifat atau Kualitas. Diakses pada 24 Juli 2018 pada: https://id.scribd.com/document/32928 8904/Panelis-Adalah-Sekelompok-
Orang-Yang-Bertugas-Menilai-Sifat-

Atau-Kualitas-Bahan-BerdasarkanKesan-Subyektif

Koswara, S. (2013). Pengolahan Ubi Jalar. Diakses pada 24 Juli 2018 pada: http://seafast.ipb.ac.id/tpc-project/wpcontent/uploads/2014/03/pengolahanubijalar1.pdf

Nurjani, A. (2018). Fenomena Kue Artis. Diakses pada 24 Juli 2018 pada: https://lifestyle.sindonews.com/read/1 273289/185/fenomena-kue-artis$1515805664 / 13$

Pertiwi F., N.L.M. (2014). Berburu Pie Susu Khas Bali. Diakses pada 24 Juli 2018 pada:

https://travel.kompas.com/read/2014/ 06/19/1013375/Berburu.Pie.Susu.Khas Bali

Puspitasari, S. (2011). Potensi Wisata Agro Kabupaten Bandung Berdasarkan Aspek Permintaan dan Penawaran. Jurnal Perencanaan dan Wilayah dan Kota, Vol. 22(1), 33-48

Rosyad, L. (2016). Pengembangan produk pangan. Diakses 24 Juli 2018 pada: https://www.scribd.com/document/32 5453591/PENGEMBANGAN-PRODUKPANGAN-pdf

Santosa, I., et al. (2016). Kajian Sifat Kima dan Uji Sensori Tepung Ubi Jalar Putih Hasil Pengeringan Cara Sangrai. Diakses pada 24 Juli 2018 pada: http://darsatop.lecture.ub.ac.id/2015/0 3/tepung-ubi-jalar/

Sugiyono. (2013). Metode Penelitan Kuantitatif Kualitatif dan R\&D. Bandung: Alfabeta

Svensson, L. (2012). Design and Performance of Small Scale Sensory Consumer Test. Diakses pada 24 Juli 2018 pada: https://stud.epsilon.slu.se/5045/1/sve nsson l 121108.pdf 